\title{
Was PolyMASC's early demise self-inflicted?
}

At the end of May the gene therapy firm Valentis (Burlinghame, CA) merged with the polymer coating firm PolyMASC (London). Under terms of the deal, Valentis will exchange newly issued shares of common stock, worth nearly \$20 million for PolyMASC common stock, at a premium of $36 \%$. In essence, PolyMASC had simply run out of money. This is not unusual for biotechnology companies especially in the current investment climate when industry analysts have been predicting rampant consolidation over the next 12 months. However, PolyMASC may have wrought its own early demise by shunning conventional financing routes.

PolyMASC was spun directly out of the University of London's Royal Free Hospital School of Medicine in August 1995. Unusually, it dispensed with venture capital investment-and the business development guidance that comes with it-by raising its first tranche of capital through an initial public offering (IPO) on the Alternative Investment Market (AIM). AIM is a stock exchange for small, highrisk firms and is affiliated with the London Stock Exchange (LSE). Its listing rules are more relaxed than those of the LSE, and companies with virtually no trading history or products in development are able to raise money. The problems for companies listing on AIM start if they need to go back to AIM or other financial markets for more money.

In PolyMASC's case, the company raised $\mathfrak{E} 5$ million ( $\$ 8$ million) at IPO (companies listing on the LSE must raise at least $£ 10$ million) giving it a valuation of $£ 20$ million. Subsequently, the company raised just another $\mathfrak{E} 0.7$ million. In the run-up to the recent Valentis merger, PolyMASC had less than $\mathfrak{E} 1$ million in cash while its expen-

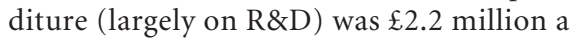
year.

According to PolyMASC's CEO Gillian Francis, the firm's potential for independence has decreased in recent years. "If you had asked two years ago, I would have said the chances were very good. It's since the market dropped that it's become much harder." Francis notes that PolyMASC and other very small companies have had a doubly difficult time over the last few years. Not only has biotechnology been out of favor with investors because of the high risks involved, but managers of large funds, making minimum investments of $\mathfrak{1} 10 \mathrm{mil}$ lion, have ignored small companies.

Other small biotechnology-related firms on AIM have struggled to raise money. The drug delivery firm Alizyme (Cambridge, UK), for example, only managed to raise $\mathfrak{£} 5$ million in its IPO in 1996 , and has only raised a further $\mathfrak{E} 6.3$ million (\$10.3 million) since. Likewise, Oxford BioMedica initially raised just under $\mathfrak{E} 5$ million on AIM at the end of 1996, and has only managed to scrape together another $£ 10$ million since then. And SR Pharma (London), formerly Stanford Rook, has raised only $\mathfrak{E} 6.6$ million ( $\$ 11$ million) since listing on AIM in 1995.

By coincidence, May 1999 saw the end of another small UK company, Proteus (Stockport, UK), when it merged with Therapeutic Antibodies (London). In 1989, Proteus became the first biotechnology company to raise money on the Unlisted Securities Market (USM), another relatively unregulated market and predecessor to AIM. Like PolyMASC, Proteus had no venture backing before its listing, although it did have some financial support from a group of local business angels.

It is widely accepted that, until the arrival of Jurek Sikorski as CEO in the late 1990s, Proteus had developed with no clear market or business focus. It failed to leverage its technical prowess in computational biology and lost the faith of its investors.

Sikorski, now CEO at Cantab Therapeutics (Cambridge, UK), says that there are two main problems with going directly to the public markets without the use of venture capitalists. The first and most obvious is that the money the venture capitalists could have put in is not invested. More importantly, however, the experience of venture capital companies in helping to ensure that a company has a good business plan, the right management, and access to the right business oportunities are lost. If a firm does not receive these things it is less likely to succeed from the start, says Sikorski.

Ronald Openshaw, an analyst with West LB Panmure (London) who orchestrated the Proteus merger, expects to see more acquisitions and mergers involving companies on AIM. "These are the sorts of companies that we look at when doing mergers. [They] don't have money but do have technology."

Adam Michael 